\title{
IMPLEMENTASI MODEL PROCESS ORIENTED GUIDED INQUIRY LEARNING (POGIL) BERBANTUAN LKS UNTUK MENINGKATKAN KREATIVITAS DAN PRESTASI BELAJAR SISWA KELAS X MIA PADA MATERI POKOK SISTEM PERIODIK UNSUR SEMESTER 1 SMA BATIK 2 SURAKARTA TAHUN AJARAN 2015/2016
}

\author{
Eva Fitria Wahyujati, Agung Nugroho Catur Saputro*, dan Sri Yamtinah \\ Program Studi Pendidikan Kimia, FKIP, Universitas Sebelas Maret, Surakarta, Indonesia \\ *keperluan korespondensi, hp: 081329023054, email: anc_saputro@yahoo.co.id
}

\begin{abstract}
ABSTRAK
Penelitian ini bertujuan untuk meningkatkan kreativitas dan prestasi belajar siswa pada materi Sistem Periodik Unsur kelas X MIA 3 SMA Batik 2 Surakarta melalui penerapan model pembelajaran Process Oriented Guided Inquiry Learning (POGIL) berbantuan LKS. Penelitian ini merupakan Penelitian Tindakan Kelas (PTK) yang dilaksanakan dalam dua siklus. Subjek dalam penelitian adalah siswa kelas X MIA 3 SMA Batik 2 Surakarta tahun ajaran 2015/2016. Sedangkan objek penelitian adalah kreativitas dan prestasi belajar pada materi sistem periodik unsur. Sumber data berasal dari guru dan siswa. Pengumpulan data prapenelitian dilakukan dengan wawancara, kajian dokumen, dan tes awal kreativitas siswa. Data kreativitas siswa dan prestasi belajar aspek pengetahuan diperoleh melalui tes, data prestasi belajar aspek sikap diperoleh melalui angket, observasi, dan wawancara, dan data prestasi belajar aspek keterampilan diperoleh melalui observasi. Data dianalisis dengan metode deskriptif. Hasil penelitian menunjukkan bahwa implementasi model pembelajaran POGIL berbantuan LKS dapat meningkatkan kreativitas dan prestasi belajar siswa pada materi Sistem Periodik Unsur. Peningkatan kreativitas siswa dilihat dari kenaikan persentase ketuntasan pada siklus I sebesar $57,89 \%$ dan siklus II sebesar $71,05 \%$. Peningkatan prestasi belajar dapat dilihat dari persentase ketuntasan antar siklus, dimana siklus I sebesar $60,53 \%$ dan siklus II sebesar $89,47 \%$. Peningkatan aspek sikap juga dapat dilihat dari persentase ketuntasan antar siklus, dimana siklus I sebesar $94,74 \%$ dan siklus II sebesar $97,37 \%$. Aspek keterampilan pada siklus I memiliki persentase ketuntasan sebesar $100 \%$, sehingga tidak diulang pada siklus II.
\end{abstract}

Kata Kunci: Process Oriented Guided Inquiry Learning (POGIL), kreativitas siswa, prestasi belajar, sistem periodik unsur

\section{PENDAHULUAN}

Pendidikan merupakan hal yang paling penting dan berpengaruh besar terhadap masa depan dan kualitas suatu bangsa. Oleh karena itu, setiap bangsa mengupayakan berbagai cara untuk memajukan pendidikannya, antara lain dengan memperbaiki kurikulum yang digunakan, memperbaiki metode serta model pembelajaran yang digunakan agar tepat dan sesuai dengan materi yang disampaikan. Melalui pendidikan yang berkualitas, akan melahirkan sumber daya manusia yang berkualitas pula yang nantinya akan membawa pengaruh besar terhadap pembangunan dan kemajuan bangsanya.

Pendidikan Sains, khususnya pendidikan kimia memegang peranan penting dalam upaya mempersiapkan sumber daya manusia yang berkualitas. Pendidikan sains memerlukan kemampuan pengolahan informasi, berpikir kritis dan kemampuan analisis, pemecahan masalah, kemampuan mengkomunikasikan, kerja tim, manajemen dan penilaian yang diperlukan untuk menghadapi persaingan global [1]. 
Agar berhasil sesuai tujuannya, perlu diperhatikan juga beberapa faktor yang mempengaruhi prestasi belajar, yaitu faktor internal dan eksternal. Faktor internal ialah faktor yang timbul dari dalam anak itu sendiri, seperti kesehatan, inteligensi, kesiapan, minat, dan sebagainya, sedangkan faktor eksternal ialah faktor yang datang dari luar diri si anak, seperti suasana rumah, lingkungan, metode yang digunakan, kurikulum, alat pelajaran, dan sebagainya [2].

Berdasarkan hasil observasi selama PPL di SMA Batik 2 Surakarta, pembelajaran yang dilakukan di kelas masih didominasi oleh guru. Guru menyampaikan dengan metode ceramah yang sesekali dilengkapi dengan tanya jawab. Tanya jawab yang berlangsung di kelas hanya melibatkan beberapa siswa yang aktif saja. Siswa cenderung mendengarkan dan mencatat materi sehingga pembelajaran menjadi membosankan dan mudah dilupakan. Hal tersebut menunjukkan bahwa pembelajaran dengan metode ceramah dan tanya jawab masih kurang efektif. Selain itu, dampak yang muncul adalah siswa cenderung tidak bisa mengerjakan soal yang sifatnya pengembangan konsep, karena siswa cenderung mengerjakan soal sesuai dengan yang telah dicontohkan oleh guru. Hal ini berarti bahwa pemahaman konsep dan kreativitas siswa masih rendah.

Berdasarkan wawancara dengan Bapak Ispriyanto selaku guru mata pelajaran kimia, materi yang ketuntasannya masih rendah adalah Sistem Periodik Unsur karena materi ini merupakan materi yang mendasar dan baru bagi siswa kelas X MIA. Selama 3 tahun terakhir, diketahui bahwa persentase ketuntasan siswa masih rendah.

Persentase ketuntasan yang
rendah tersebut mengindikasikan adanya masalah dalam pembelajaran kimia. Berdasarkan hasil observasi dan wawancara tersebut, peneliti mengupayakan penggunaan model pembelajaran yang tepat yakni yang memungkinkan siswa untuk membentuk sendiri konsep materi yang dipelajari, sehingga diharapkan mampu mengasah kreativitas siswa, dan diharapkan siswa mampu mengingat serta benar-benar paham. Sehingga nantinya diharapkan model pembelajaran tersebut mampu meningkatkan prestasi belajar dan kreativitas siswa dalam materi Sistem Periodik Unsur (SPU).

Tabel 1. Persentase Ketuntasan Siswa pada materi Sistem Periodik Unsur

\begin{tabular}{cccc}
\hline \multirow{2}{*}{ Tahun } & \multicolumn{3}{c}{ Ketuntasan (\%) } \\
\cline { 2 - 4 } Ajaran & X MIA & X MIA & X MIA \\
& 1 & 2 & 3 \\
\hline $2012 / 2013$ & 71 & 58,1 & 85,7 \\
$2013 / 2014$ & 77,4 & 67,7 & 70,6 \\
$2014 / 2015$ & 44,1 & 35,3 & 18,4 \\
\hline
\end{tabular}

Salah satu faktor yang mempengaruhi prestasi belajar adalah kreativitas siswa. Kreativitas memiliki ciriciri kemampuan yang meliputi kelancaran, kelenturan, dan orisinalitas dalam berpikir, dan ciri-ciri tersebut dioperasionalisasikan dalam tes berpikir ke segala arah atau tes berpikir divergen [3]. Kreativitas inilah yang akan membantu siswa dalam proses pembentukan konsep dan selanjutnya menggabungkan konsep satu dengan konsep yang lainnya untuk memecahkan masalah yang diberikan oleh guru.

Berdasarkan hasil observasi dan wawancara dengan guru, siswa cenderung menerima informasi dari guru tanpa mencoba mencari sendiri atau mengkonstruksi pengetahuannya sendiri. Kebiasaan tersebut mengakibatkan siswa mengalami kesulitan ketika diberikan soal yang sifatnya pengembangan ataupun penggabungan dari beberapa konsep. Hal tersebut berimbas pada prestasi belajar siswa yang cenderung rendah. Oleh karena itu, dengan mengasah krestivitas siswa melalui pembentukan konsep, diharapkan mampu meningkatkan pemahaman dan kemampuan berpikir siswa dalam menyelesaikan soal, sehingga prestasi belajar siswa meningkat.

Untuk mengasah dan meningkatkan kreativitas siswa dalam proses mengkonstruksi konsep mereka sendiri, perlu 
adanya pemilihan model pembelajaran yang tepat. Sehingga diharapkan pembelajaran menjadi lebih bermakna daripada sekedar menerima informasi dari guru maupun menghafal teori-teori yang ada. Dengan pemilihan model pembelajaran yang memfasilitasi siswa untuk mengasah kreativitasnya dalam mengkonstruksi konsep sendiri, diharapkan siswa dapat menyelesaikan soal yang bersifat pengembangan, sehingga prestasi belajar siswa dapat meningkat.

Model pembelajaran yang diharapkan mampu meningkatkan kreativitas dan prestasi belajar siswa dalam materi Sistem Periodik Unsur adalah model pembelajaran Process Oriented Guided Inquiry Learning (POGIL). Dalam proses pembelajarannya, siswa membangun sendiri konsep dari materi yang dipelajari dengan melalui serangkaian tahap yakni eksplorasi, pembentukan konsep, aplikasi, diskusi dan berbagi informasi dengan siswa yang lain, merefleksi pembelajaran yang telah dilakukan, dan menilai hasil siswa [4]. Dalam model pembelajaran POGIL, siswa dibagi menjadi beberapa kelompok yang umumnya terdiri dari tiga sampai empat siswa [5].

Pada tahap eksplorasi, siswa meng-eksplor model (dapat berupa data, tabel, grafik, gambar, dll.) yang telah disedia-kan guru. Pada tahap pembentukan konsep, siswa diminta menuangkan hasil pengamatannya dengan cara menjawab pertanyaan-pertanyaan yang diberikan secara runut hingga sampai pada tahap siswa membentuk suatu konsep. Setelah konsep terbentuk, siswa mengaplikasi-kan konsep yang telah mereka bentuk untuk mengerjakan beberapa soal yang sifatnya lebih mendalam. Selanjutnya pada tahap penutup, siswa mengevaluasi hasil diskusi mereka dengan cara mempresentasikan dan memban-dingkan hasil diskusi mereka dengan kelompok yang lain [5].

Pemilihan model pembelajaran tersebut juga didasarkan pada hasil penelitian sebelumnya yang telah dilakukan oleh Widyaningsih (2012) tentang Model MFI dan POGIL ditinjau dari aktivitas belajar dan kreativitas siswa terhadap prestasi belajar. Hasil dari penelitian tersebut menunjukkan bahwa prestasi belajar siswa dengan model pembelajaran POGIL lebih tinggi daripada prestasi belajar siswa dengan model pembelajaran MFI. Dalam penelitian tersebut juga disebutkan bahwa adanya interaksi antara model pembelajaran POGIL dan MFI dengan kreativitas siswa terhadap prestasi belajar [6]. Selain itu, penelitian yang dilakukan oleh Zawadzki (2010), menyatakan bahwa kemampuan penguasaan siswa terhadap materi umumnya lebih tinggi dibandingkan dengan metode konvensional; siswa umumnya lebih menyukai pembelajaran dengan pendekatan POGIL daripada pendekatan konvensional; siswa umum-nya memiliki sikap yang lebih positif terhadap materi pelajaran dan guru; keterampilan belajar siswa tampak untuk meningkatkan hasil ulangan semester [1].

Dalam model pembelajaran POGIL, siswa dituntut untuk membentuk konsep sendiri. Oleh karena itu, bimbingan guru sangat diperlukan agar konsep yang terbentuk sesuai dengan yang diharap-kan, yakni melalui media pembelajaran Lembar Kerja Siswa (LKS) yang di dalamnya mencakup sintak model POGIL sehingga pembentukan konsep oleh siswa dapat terarah dengan baik. Hal tersebut didasarkan pada penelitian yang dilakukan oleh Rosidah (2013), menyatakan bahwa dengan mengguna-kan model pembelajaran POGIL berbantuan LKPD (Lembar Kegiatan Peserta Didik), siswa yang dikenai pem-belajaran dengan menggunakan model POGIL memiliki kemampuan pemecahan masalah lebih tinggi dibandingkan dengan siswa yang dikenai model pembelajaran konvensional. Berdasar-kan penelitian tersebut, LKS (Lembar Kerja Siswa) digunakan sebagai media untuk mengarahkan siswa dalam mengkonstruksi pengetahuannya [7].

Berdasarkan uraian di atas, peneliti perlu mengadakan Penelitian Tindakan Kelas (PTK) di SMA Batik 2 Surakarta dengan menggunakan model pembelajaran Process Oriented Guided Inquiry Learning (POGIL) berbantuan LKS. Penelitian ini diharapkan dapat meningkatkan kreativitas dan prestasi 
belajar siswa kelas X MIA 3 pada materi Sistem Periodik Unsur.

\section{METODE PENELITIAN}

Penelitian ini merupakan penelitian tindakan kelas (Classroom Action Research) yang dilaksanakan dalam dua siklus dimana pada setiap siklus terdiri dari beberapa tahap yaitu persiapan, perencanaan, pelaksanaan, observasi, dan refleksi.

Subjek penelitian adalah siswa kelas X MIA 3 semester ganjil SMA Batik 2 Surakarta tahun pelajaran 2015/2016. Obyek penelitian ini adalah kreativitas dan prestasi belajar siswa.

Data penelitian yang dikumpul- kan dalam penelitian ini meliputi data informasi tentang keadaan siswa secara aspek kualitatif dan kuantitatif. Aspek kualitatif meliputi data lapangan tentang hasil observasi, wawancara, kajian dokumen atau arsip yang menggambarkan proses belajar mengajar di kelas, kesulitan yang dialami guru ketika proses belajar mengajar serta model pembelajaran yang biasa digunakan. Aspek kuantitatif meliputi data penilaian prestasi belajar siswa pada materi sistem periodik unsur yang meliputi aspek pengetahuan, sikap, dan keterampilan baik siklus I maupun siklus II.

Teknik pengumpulan data dilakukan dengan tes, observasi, wawancara dan angket. Instrumen diujicobakan terlebih dahulu dan dilaksanakan di kelas yang tidak digunakan penelitian dan divalidasi isi oleh dua panelis. Analisis data dilakukan dalam tiga tahap yaitu reduksi data, penyajian data dan penarikan kesimpulan [8].

\section{HASIL DAN PEMBAHASAN}

Berdasarkan hasil wawancara, tes dan observasi, terdapat permasalahanpermasalahan yang dapat disimpulkan bahwa di kelas X MIA 3 mempunyai permasalahan yaitu pada kreativitas dan prestasi belajar yang rendah. Oleh karena itu, perlu adanya upaya untuk mengatasi permasalah tersebut dengan mene-rapkan model pembelajaran yang sesuai.

Berdasarkan hasil observasi dan wawancara terhadap guru mata pelajaran kimia dapat disimpulkan bahwa siswa mengalami kesulitan dalam mempelajari materi sistem periodik unsur. Kreativitas siswa tergolong rendah. Penelitian dilaksanakan dalam 2 siklus.

\section{Siklus I}

\section{a. Perencanaan}

Tahap ini meliputi penyusunan Rencana Pelaksanaan Pembelajaran (RPP) dan LKS yang merujuk pada silabus kurikulum 2013, penyusunan instrumen penilaian meliputi penilaian aspek pengetahuan, sikap, dan keterampilan; serta penyusunan instrumen tes kreativitas verbal.. Siklus I terdiri dari 3 kali pertemuan untuk menyampaikan materi dan 1 kali untuk evaluasi.

\section{b. Pelaksanaan Tindakan}

Siklus I dilaksanakan pada tanggal 14 September-23 September 2015. Pada tahap awal pembelajaran, Guru mengawali pembelajaran dengan memberikan beberapa pertanyaan yang berkaitan dengan materi dan dihubungkan dalam kehidupan sehari-hari. Hal tersebut bertujuan untuk membangkitkan keingintahuan siswa mengenai materi yang akan dipelajari. Selanjutnya, guru mempersilahkan siswa untuk duduk bergabung dengan kelompok yang telah ditentukan. Guru membagikan Lembar Kerja Siswa (LKS) kepada setiap siswa.

Tahap berikutnya adalah eksplorasi. Pada tahap ini, siswa mengeksplorasi data yang diberikan di dalam LKS. Data tersebut berupa gambar, tabel, dan lain sebagainya. Siswa aktif menyampaikan pendapatnya dan berdiskusi dengan kelompoknya.

Sintak selanjutnya adalah pembentukan konsep. Data yang telah dieksplorasi oleh siswa, selanjutnya digunakan siswa untuk menjawab 
pertanyaan-pertanyaan yang menuntun siswa dalam pembentukan konsep. Pertanyaan-pertanyaan tersebut dibuat terstruktur untuk menuntun siswa berpikir kritis dan menganalisis bahan belajar yang diberikan. Pertanyaan tersebut bertujuan untuk menuntun siswa dalam mengeksplorasi bahan belajar sehingga konsep yang terbentuk oleh siswa terarah dengan baik. Siswa menjawab pertanyaan yang terdapat dalam LKS dengan menggunakan kalimat mereka sendiri.

Tahap selanjutnya adalah tahap aplikasi. Setelah siswa menemukan dan mengkonstruksi konsep mereka sendiri, siswa mulai mengaplikasikan konsep tersebut untuk menyelesaikan suatu permasalahan atau soal yang lebih mendalam. Soal yang diberikan bertujuan untuk menguatkan dan memperluas konsep yang telah dibentuk oleh siswa.

Tahap terakhir adalah penutup. Siswa mempresentasikan hasil diskusi mereka untuk dibandingkan dengan hasil diskusi kelompok yang lain. Pada tahap akhir, guru menyamakan persepsi agar konsep yang terbentuk sesuai dengan yang seharusnya. Pada akhir pembelajaran, guru memberikan post test untuk mengetahui sejauh mana penyerapan siswa terhadap materi yang dipelajari. Pembelajaran diakhiri dengan guru memberitahukan materi yang akan dipelajari selanjutnya..

\section{c. Pengamatan}

Data yang diperoleh dalam penelitian ini adalah data kreativitas siswa, dan prestasi belajar siswa yang meliputi aspek pengetahuan, sikap, dan keterampilan.

Pada penelitian ini, pengukuran kreativitas dilakukan dengan instrumen tes kreativitas verbal yang meliputi (1) permulaan kata, (2) menyusun kata, (3) membentuk kalimat tiga kata, (4) sifatsifat yang sama, (5) macam-macam penggunaan dan (6) apa akibatnya. Ringkasan hasil penilaian kreativitas siswa disajikan dalam Tabel 2.

Target keberhasilan kreativitas siswa adalah 65\%. Ketidaktercapaian tersebut dipengaruhi oleh beberapa faktor, diantaranya siswa mengaku dalam keadaan lelah saat mengerjakan dan merupakan tes yang asing bagi siswa, sehingga dalam mengerjakan tes menjadi kurang optimal.

Tabel 2. Hasil Penilain Kreativitas Siswa Siklus I

\begin{tabular}{lc}
\hline \multicolumn{1}{c}{ Kriteria } & Ketercapaian (\%) \\
\hline Tinggi & 57,89 \\
Sedang & 31,58 \\
Rendah & 10,53 \\
\hline
\end{tabular}

Data prestasi belajar siswa aspek pengetahuan diambil pada akhir siklus I berupa tes objektif. Ringkasan hasil penilaian aspek pengetahuan disajikan dalam Tabel 3.

Tabel 3. Hasil Penilaian Aspek Pengetahuan Siklus I

\begin{tabular}{cc}
\hline Kategori & Ketercapaian (\%) \\
\hline Tuntas & 60,53 \\
Tidak Tuntas & 39,47 \\
\hline
\end{tabular}

Target ketuntasan aspek pengetahuan adalah $70 \%$. Penyebab belum tercapainya ketuntasan dikarenakan materi pada indikator 3 dan 5 tergolong materi yang lebih sulit apabila dibandingkan dengan materi dari indikator lain.Hasil dari siklus I menunjukkan masih diperlukan perbaikan terhadap pembelajaran yang dilaksanakan agar ketuntasan belajar siswa meningkat. Oleh karena itu, dilakukan serangkaian perencanaan untuk pelaksanaan siklus II.

Data prestasi belajar aspek sikap didapatkan berdasarkan observasi selama pembelajaran, angket, dan wawancara. Target ketuntasan aspek sikap adalah $80 \%$.. Ringkasan hasil penilaian aspek sikap disajikan dalam Tabel 4.

Tabel 4. Hasil Penilaian Aspek Sikap Siklus I

\begin{tabular}{cc}
\hline Kategori & Capaian (\%) \\
\hline Sangat Baik & 26,32 \\
Baik & 68,42 \\
Cukup & 5,26 \\
\hline
\end{tabular}


Data prestasi belajar aspek keterampilan didapat melalui observasi. Aspek yang dinilai adalah perencanaan proyek, pelaksanaan proyek, dan produk. Perolehan nilai akhir berdasarkan nilai optimum dari ketiga aspek tersebut. Hasil penilaian menunjukkan bahwa persentase ketuntasan siswa sebesar $100 \%$. Hasil tersebut sudah melampaui target yang ditetapkan. Sehingga pada siklus II, penilaian aspek keterampilan tidak dilakukan.

\section{d. Refleksi}

Dari target keberhasilan pada siklus I dapat diketahui bahwa persentase ketercapaian aspek pengetahuan dan kreativitas siswa belum mencapai target. Sehingga perlu dilakukan perbaikan pada siklus II. Tindakan siklus II diharapkan mampu menuntaskan kedua indikator kompetensi yang belum mencapai target ketuntasan. Selain mengupayakan untuk meningkatkan hasil belajar, juga diupayakan untuk mempertahankan pencapaian prestasi belajar yang telah tercapai dan diupayakan adanya peningkatan yang lebih tinggi dari target yang sudah dicapai di siklus I.

Berdasarkan analisis hasil tes pengetahuan siklus I terlihat bahwa terdapat 2 indikator yang belum mencapai target, yaitu indikator 3 dengan persentase ketercapaian $57,02 \%$ dan indikator 5 dengan persentase ketercapaian $55,79 \%$. Indikator yang belum tuntas adalah meramalkan letak ataupun nomor atom suatu unsur dalam sistem periodik unsur dan menyimpulkan sifat keperiodikan unsur dalam sistem periodik unsur. Pada indikator 3, kebanyakan siswa kurang teliti dalam menentukan letak dan nomor atom unsur. Sedangkan pada indikator 5, siswa masih merasa kebingungan untuk membedakan sifat-sifat keperiodikan unsur.

Pelaksanaan siklus II berbeda dengan siklus I. Perbedaan dari siklus I dan II adalah pada siklus I dalam satu kelompok terdiri dari 4-5 siswa, sedangkan pada siklus II setiap kelompoknya terdiri dari 2 siswa, dengan ketentuan terdapat satu siswa yang sudah tuntas pada setiap kelompok. Selain itu, guru hanya memfokuskan materi pada 2 indikator yang belum tuntas saja.

\section{Siklus II}

\section{a. Perencanaan}

Peneliti dan guru melakukan tahap perencanaan tindakan siklus II dengan berdasar kepada hasil refleksi siklus I. Pembelajaran siklus II dilaksanakan dalam 3x pertemuan. Pembelajaran siklus II direncanakan dalam RPP yang lebih berfokus pada 2 indikator yang belum tuntas.

Siklus II pada penelitian ini terdiri dari 2 kali pertemuan untuk pendalaman materi dan 1 kali untuk evaluasi. Materi yang disampaikan pada siklus II merupakan materi pada indikator kompetensi yang belum tuntas pada evaluasi siklus I. Dari analisis aspek pengetahuan, masih terdapat dua indikator kompetensi yang belum dikuasai siswa yaitu meramalkan letak ataupun nomor atom suatu unsur dalam sistem periodik unsur dan menyimpulkan sifat keperiodikan unsur dalam sistem periodik unsur.

\section{b. Pelaksanaan Tindakan}

Seperti pada siklus I, guru memulai pembelajaran dengan mengingatkan kembali mengenai materi sebelumnya melalui pertanyaan-pertanyaan pancingan. Kemudian dilanjutkan dengan siswa berdiskusi bersama kelompoknya.

Pada siklus II, pembagian kelompok dibuat lebih sedikit daripada siklus I, yakni dalam satu kelompok hanya terdiri dari 2 siswa. Dimana pembagian siswa ke dalam kelompok dibuat secara heterogen dengan berdasarkan kepada nilai ulangan yang telah dilaksanakan pada siklus I. siswa yang sudah tuntas dipasangkan dengan siswa yang belum tuntas agar dapat membantu siswa dalam menguasai materi yang akan diberikan.

\section{c. Pengamatan}

Penilaian terhadap aspek pengetahuan siswa dilaksanakan pada akhir siklus berupa soal pilihan ganda yang terdiri dari 10 butir soal pada indikator yang belum tercapai di siklus I. 
Ringkasan hasil pengambilan data prestasi belajar aspek pengetahuan dan sikap siswa pada siklus II disajikan dalam Tabel 5 dan Tabel 6.

Tabel 5. Hasil Penilaian Aspek Pengetahuan Siklus II

\begin{tabular}{cc}
\hline Kategori & Persentase (\%) \\
\hline Tuntas & 89,47 \\
Tidak Tuntas & 10,53 \\
\hline
\end{tabular}

Tabel 6. Hasil Penilaian Aspek Sikap Siklus II

\begin{tabular}{cc}
\hline Kategori & Capaian (\%) \\
\hline Sangat Baik & 42,11 \\
Baik & 55,26 \\
Cukup & 2,63 \\
\hline
\end{tabular}

Ringkasan hasil kreativitas siswa pada siklus II disajikan dalam Tabel 7 .

Tabel 7. Hasil Penilaian Kreativitas Siswa Siklus II

\begin{tabular}{lc}
\hline \multicolumn{1}{c}{ Kriteria } & Ketercapaian (\%) \\
\hline Tinggi & 71,05 \\
Sedang & 23,68 \\
Rendah & 5,26 \\
\hline
\end{tabular}

Berdasarkan analisis hasil penilaian siklus II, dapat disimpulkan bahwa persentase ketercapaian siklus II telah melampaui target yang ditentukan sebelumnya. Hal tersebut menunjukkan bahwa model pembelajaran POGIL yang dilengkapi dengan LKS mampu meningkatkan kreativitas dan prestasi belajar siswa.

\section{Perbandingan Antar Siklus}

Secara umum, pembelajaran pada siklus II mempunyai hasil yang lebih baik dibandingkan dengan siklus I.

$\mathrm{Hal}$ ini menunjukkan bahwa pemberian tindakan pada siklus II dapat meningkatkan kreativitas siswa menjadi lebih tinggi. Peningkatan presentase siswa dengan kreativitas tinggi ini juga ditunjukkan dengan semakin banyaknya siswa yang terlibat aktif dalam pembelajaran.

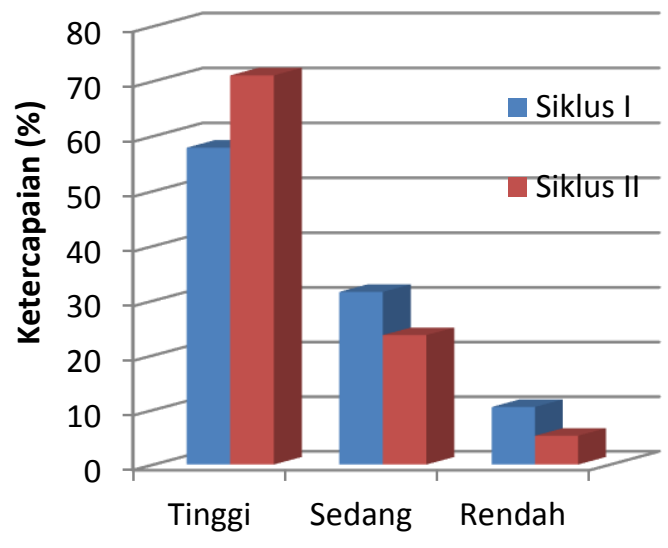

Kriteria Kreativitas

Gambar 1. Perbandingan hasil penilaian kreativitas antarsiklus

Pada aspek pengetahuan juga mengalami peningkatan yang cukup signifikan. Perbandingan hasil penilaian aspek pengetahuan antarsiklus tersaji pada gambar 2 .

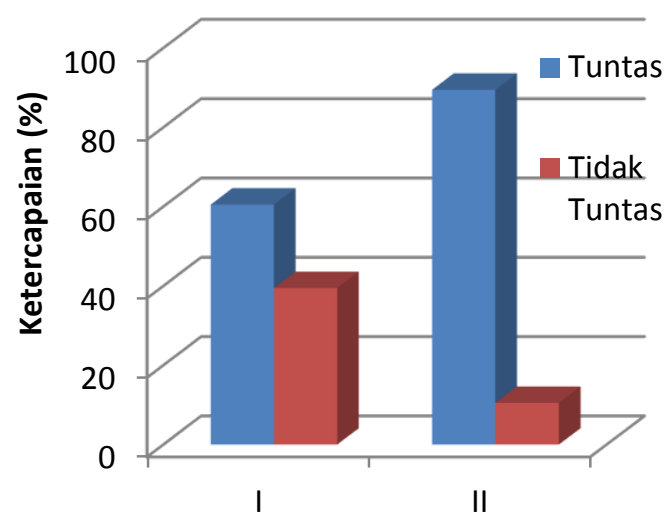

Siklus

Gambar 2. Perbandingan hasil penilaian aspek pengetahuan antarsiklus.

Hasil penilaian aspek sikap siklus II juga menunjukkan adanya peningkatan. Hal tersebut menunjukkan bahwa sikap siswa selama proses pembelajaran dengan menggunakan model POGIL tersebut menunjukkan perubahan sikap yang semakin baik. Perbandingan hasil penilaian aspek sikap antarsiklus tersaji pada gambar 3 . 


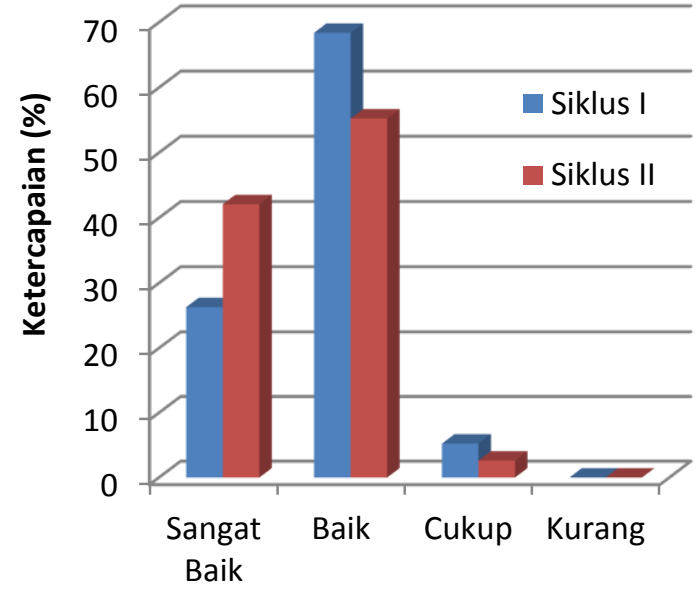

Gambar 3. Perbandingan hasil penilaian aspek sikap antarsiklus

Berdasarkan hasil penilaian yang telah dilakukan, penelitian dengan menggunakan model pembelajaran Process Oriented Guided Inquiry Learning (POGIL) berbantuan LKS pada materi Sistem Periodik Unsur dapat dikatakan berhasil karena semua aspek penilaian telah memenuhi target yang ditentukan yaitu meningkatkan kreativitas dan prestasi belajar siswa kelas X MIA 3 SMA Batik 2 Surakarta tahun ajaran 2015/2016. Pada penelitian ini, pelaksanaan tindakan hanya dilakukan sampai dengan siklus II.

\section{KESIMPULAN}

Berdasarkan penelitian yang pernah dilakukan, dapat disimpulkan bahwa penerapan model pembelajaran Process Oriented Guided Inquiry Learning (POGIL) berbantuan LKS dapat meningkatkan kreativitas dan prestasi belajar siswa pada materi Sistem Periodik Unsur kelas X MIA 3 SMA Batik 2 Surakarta tahun ajaran 2015/2016.

\section{UCAPAN TERIMA KASIH}

Penelitian ini dapat selesai dengan baik karena bantuan dari berbagai pihak. Oleh karena itu, penulis mengucapkan terima kasih kepada Bapak Drs. H. Soewarto, M.M. selaku Kepala SMA Batik 2 Surakarta yang telah mengijinkan peneliti melakukan penelitian di SMA
Batik 2 Surakarta dan kepada Bapak Ispriyanto, M.Pd. selaku guru kimia SMA Batik 2 Surakarta yang telah berkenan mengijinkan peneliti melaksanakan penelitian di kelas yang belau ampu dan berkolaborasi dengan peneliti demi terselesaikannya penelitian.

\section{DAFTAR RUJUKAN}

[1] Zawadzki, R. (2010). Asian Journal on Education and Learning, 1 (2), 66-74.

[2] Slameto. (2013). Belajar dan Faktorfaktor yang Mempengaruhi. Jakarta: Rineka Cipta.

[3] Munandar, U. (2012). Pengembangan Kreativitas Anak Berbakat. Jakarta: Rineka Cipta.

[4] Bransford, J. D., Brown, A. L., Crocking, R. R. \& editors. (2000). How People Learn. Washington DC: National Academy Press.

[5] Chase, A., Pakhira, D., \& Stains, M. (2013). Chemical Education 90:4 2013, 409-416.

[6] Widyaningsih, S. Y., Haryono, Saputro, S. (2012). Surakarta: Jurnal Inkuiri Pasca UNS, Vol. 1 No. $3 \mathrm{Hal}$. 266-275.

[7] Rosidah. (2013). Semarang: Jurnal Kreano UNNES, Vol. 4 No. 1 Hal. 7379.

[8] Miles, M. B., \& Huberman, A. M. (1992). Analisis Data Kualitatif: Buku Sumber tentang Metode-metode Baru. Terjemahan: Tjetjep Rohendi Rohidi. Jakarta: Universitas Indonesia Press. 